\title{
Kemampuan Komunikasi Matematis Siswa dengan Pendekatan Pembelajaran Matematika Realistik Bernuansa Etnomatematika (PMRE)
}

\author{
Muslimahayati \\ Program Studi Pendidikan Matematika, Fakultas Ilmu Tarbiyah dan Keguruan, Universitas Islam Negeri \\ Raden Fatah Palembang, Jl. Prof. K. H. Zainal Abidin Fikri No.Kel, Pahlawan, Kec. Kemuning, \\ Palembang, Indonesia \\ email: muslimahayati uin@radenfatah.ac.id \\ (Received 13-03-2019, Reviewed 26-03-2019, Accepted 05-04-2019)
}

\begin{abstract}
This study examines the improvement of students mathematical communication skills if reviewed as a whole and reviewed according to the category of high, medium and low mathematical initial abilities. This research is a quasi-experimental study with nonequivalent pre-test and post-test control-group design. The sample in this study amounted to 64 students in one school in the city of Jambi, which consisted of 32 experimental class students who were given PMRE and 32 control class students who were given conventional learning. The data obtained were analyzed using $t$-test. The results showed that: 1) improvement in mathematical communication skills of students who obtained PMRE learning as a whole was better than students who obtained conventional learning with high categories 2) in terms of KAM, increased mathematical communication skills of students in the KAM category while those who obtained PMRE learning were better than students who received conventional learning, while those in the high and low KAM categories who received PMRE learning were no better than students who received conventional learning.
\end{abstract}

Keywords: Realistic Mathematics Learning, Ethnomatematics, Mathematical Communication Ability

\begin{abstract}
Abstrak
Penelitian ini mengkaji tentang peningkatan kemampuan komunikasi matematis siswa jika ditinjau secara keseluruhan dan ditinjau menurut kategori kemampuan awal matematis tinggi, sedang dan rendah. Penelitian ini merupakan penelitian quasi experiment dengan nonequivalent pre-test and post-test control-group design. Sampel dalam penelitian ini berjumlah 64 siswa di salah satu sekolah di kota Jambi, yang terdiri dari 32 siswa kelas eksperimen yang diberikan PMRE dan 32 siswa kelas kontrol yang diberikan pembelajaran konvensional. Data yang diperoleh dianalisis menggunakan uji-t. Hasil penelitian menunjukkan bahwa: 1) peningkatan kemampuan komunikasi matematis siswa yang memperoleh pembelajaran PMRE secara keseluruhan lebih baik daripada siswa yang memperoleh pembelajaran konvensional dengan kategori tinggi 2) ditinjau dari KAM, peningkatan kemampuan komunikasi matematis siswa kategori KAM sedang yang memperoleh pembelajaran PMRE lebih baik daripada siswa yang memperoleh pembelajaran konvensional, sedangkan pada siswa kategori KAM tinggi dan rendah yang memperoleh pembelajaran PMRE tidak lebih baik daripada siswa yang mendapatkan pembelajaran konvensional.
\end{abstract}

Kata Kunci : Pembelajaran Matematika Realistik, Etnomatematika, Kemampuan Komunikasi Matematis

CPendidikan Matematika Universitas Islam Negeri Raden Fatah Palembang 


\section{PENDAHULUAN}

Kemampuan komunikasi matematika merupakan kemampuan siswa menggunakan matematika sebagai alat komunikasi (bahasa matematika), dan kemampuan siswa mengkomunikasikan matematika yang dipelajari sebagai isi pesan yang harus disampaikan (NCTM, 1989). Kemampuan komunikasi matematis merupakan bagian yang sangat penting dalam menyukseskan proses pembelajaran matematika. Tanpa komunikasi, maka proses pembelajaran akan terhambat. Berbagai permasalahan diutarakan seperti penelitian Suryadi pada tahun 2009 (Izzati \& Suryadi, 2010) yang menyatakan bahwa hampir semua siswa yang berpartisipasi dalam penelitiannya, belum memahami bagaimana menyelesaikan masalah dan menggunakan bahasa matematik yang benar. Belum ada yang menunjukan bahwa mereka memiliki kemampuan komunikasi matematik yang baik/efektif, misalnya, menggunakan istilah, simbol, tanda, dan/atau representasi yang tepat dan teliti, untuk menjelaskan operasi, konsep dan proses. Selain itu, sistematika penulisan jawaban belum tepat. Lebih memprihatinkan lagi, dari 39 siswa yang berpartisipasi, hanya 19 orang menjawab "mengarah benar". Terkait dengan salah satu indikator kemampuan komunikasi matematis siswa dalam hal mengubah situasi nyata ke dalam simbol matematika terdapat permasalahan seperti yang diungkapkan (Kaselin, Sukestiyarno, \& Waluya, 2012) dalam penelitiannya yang menunjukkan bahwa masih banyak siswa yang tidak mampu mengaitkan masalah yang dihadapi dengan konteks kejadian yang ada dalam kehidupan nyata, tidak mampu memanfaatkan data/ informasi pada soal sehingga penyelesaian menuju langkah berikutnya menjadi terhenti dan kesulitan di dalam menerapkan pengetahuan yang dipelajari sebelumnya. Selanjutnya juga diungkapkan (Putri, Syutaridho, Paradesa, \& Afgani, 2019) inovasi dalam pembelajaran matematika perlu dikembangkan secara berkelanjutan untuk meningkatkan kemampuan komunikasi matematis siswa ataupun mahasiswa.

Oleh karena itu, untuk mengembangkan kemampuan komunikasi matematis siswa Pugalee (Qohar \& Sumarmo, 2013) menyarankan "that in learning mathematics students should be encouraged to answer questions accompanied with relevant reason, and to comment a mathematical statement in their own language, so that students became to understand the mathematics concepts and arguments meaningfully”. Dengan kata lain bahwa dalam belajar matematika siswa harus didorong untuk menjawab pertanyaan disertai dengan alasan yang relevan dan untuk mengomentari pernyataan matematika dalam bahasa mereka sendiri, sehingga siswa menjadi memahami konsep dan argumen 
matematika secara bermakna". (Wijaya, 2012) mengutarakan hal yang serupa yaitu bahwa yang terpenting adalah refleksi kita terhadap praktik pembelajaran, apakah kita mengajarkan (membelajarkan) matematika sebagai bagian dari kehidupan atau sebagai suatu "makhluk" yang terisolasi dari kehidupan sehingga siswa bahkan tidak tahu untuk apa mereka belajar matematika. Selanjutnya, (Asikin \& Junaedi, 2013) juga menyatakan bahwa peran guru untuk menciptakan komunitas matematika di kelas juga sangat strategis, dalam arti bahwa porsi peran guru sebagai "pengajar" harus proporsional dengan peran lain sebagai fasilitator, partisipan atau bahkan sebagai seorang sahabat di kelas.

Penelitian ini memilih pendekatan pembelajaran matematika realistik atau Realistic Mathematics Education (RME) sebagai alternatif pembelajaran. Hal dikarenakan pembelajaran matematika realistik memilikiprinsip-prinsip dan karakteristik yang dapat meningkatkan kemampuan komunikasi matematika siswa (Isrok'atun, 2009). Siswa belajar dari adanya masalah dalam kehidupannya sehari-hari, yang pada akhirnya memunculkan sebuah konsep matematika. Lanjutnya, siswa dapat mengembangkan model-model sendiri dari masalah-masalah kontekstual, dari masalah konkret menuju situasi abstrak (formal mathematical knowledge). Melalui matematisasi horizontal, model tentang masalah berubah menjadi model untuk pengetahuan matematika informal (model of), dan melalui matematisasi vertikal berubah menjadi model pengetahuan matematika formal (model for). Dalam diskusi siswa memberikan argumen dan interpretasinya terhadap model-model yang mereka ciptakan, sehingga tercipta interaktif diantara siswa. Dengan demikian siswa belajar berkomunikasi dalam bentuk lisan. Bagaimana siswa menginterpretasikan sebuah masalah kontekstual, bagaimana siswa dapat bekerja secara interaktif, dan bagaimana siswa dapat melihat adanya keterkaitan antar topik matematika dengan topik lain, itu adalah sebagian dari kemampuan komunikasi matematik yang dapat dilatih/ditingkatkan melalui pendekatan RME (Isrok'atun, 2009). Pemilihan pembelajaran ini juga didasarkan karena pembelajaran matematika realistik sejalan dengan teori perkembangan Piaget yaitu pendekatan yang didasarkan atas tahap perkembangan siswa, teori Vygotsky dan teori belajar bermakna Ausubel.

Untuk mencapai tujuan dari penelitan ini, dilakukan inovasi pada pembelajaran matematika realistik dengan menggunakan etnomatematika sebagai konteks dalam pembelajaran. Dalam kaitannya dengan matematika, pelopor etnomatematika (De'Ambrosio, 1999) mengatakan Ethnomathematics adalah "Cara-cara atau mode-mode, 
atau gaya-gaya, seni, dan teknik untuk belajar, memahami, mengerjakan, mengatasi permasalahan lingkungan alam, lingkungan sosial, lingkungan budaya, dan bahkan lingkungan khayal, sebagai uraian dari technes dan mathema dan ethnos. Hal ini sesuai dengan pendapat (Turmidi, 2018) yang mengatakan pembelajaran berbasis budaya merupakan keniscayaan, karena munculnya matematika merupakan produk dari peradaban manusia dan merupakan proses panjang pengalaman umat manusia yang sarat dengan isu budaya. Shirley (Marsigit, Conromukti, Setiana, \& Hardiarti, 2018) juga berpandangan bahwa sekarang ini bidang etnomatematika, yaitu matematika yang tumbuh dan berkembang dalam masyarakat dan sesuai dengan kebudayaan setempat, dapat digunakan sebagai pusat proses pembelajaran dan metode pengajaran, walaupun masih relatif baru dalam dunia pendidikan. (Muslimahayati \& Wardani, 2019) menyatakan bahwa integrasi antara kebudayaan dalam hal ini kebudayaan pada kelompok masyarakat atau suku tertentu yang disertai dengan tumbuhnya aktivitas matematika (etnomatematika) dengan pembelajaran perlu untuk diterapkan guna untuk memperkenalkan sekaligus melestarikan kebudayaan bangsa serta membuat pembelajaran menjadi suatu hal yang "dekat" bagi siswa. Berdasarkan uraian latar belakang di atas, penelitian ini bertujuan untuk meningkatkan kemampuan komunikasi matematis siswa dengan pendekatan matematika realistik bernuansa etnomatematik (PMRE). Selanjutnya penelitian dilakukan pada siswa SMP kelas VII untuk materi persamaan dan pertidaksamaan linear satu variabel.

\section{METODE PENELITIAN}

Penelitian ini adalah penelitian kuasi eksperimen dengan desain berbentuk Nonequivalent Pre-Test and Post-Test Control-Group Design, dimana kelas kontrol dan kelas eksperimen tidak diambil melalui prosedur acak. Penelitian ini bertujuan untuk mengetahui peningkatan kemampuan komunikasi matematis siswa yang memperoleh pembelajaran matematika dengan pendekatan PMRE dan siswa yang memperoleh pembelajaran konvensional. Pengambilan sampel pada penelitian ini dilakukan dengan menggunakan teknik purposive sampling. Sampel dalam penelitian ini berjumlah 64 siswa SMP di salah satu sekolah di kota Jambi, yang terdiri dari 32 siswa kelas eksperimen yang diberikan PMRE dan 32 siswa kelas kontrol yang diberikan pembelajaran konvensional. Pengambilan sampel didasarkan dari perkembangan kognitif siswa SMP yang berada pada tahap peralihan dari operasi kongkrit ke operasi formal. 
Siswa SMP rata-rata berusia antara 12-15 tahun dimana perkembangan kognitif siswa berada pada tahap awal operasi formal sebagaimana disebutkan dalam teori belajar Piaget yang ditandai dengan pemikiran yang abstrak dan tidak dibatasi pada kejadian-kejadian konkret atau tahap peralihan dari operasi kongkrit ke operasi formal. Sampel dalam penelitian ini adalah siswa di salah satu sekolah di kota jambi yang berjumlah 64 siswa yang masing-masing 32 siswa untuk kelas yang menjadi kelompok kontrol dan kelas yang menjadi kelompok eksperimen.

Selanjutnya variabel dalam penelitian ini terdiri dari variabel bebas, variabel terikat dan variabel kontrol. Variabel bebas (X) ini dapat disebut sebagai variabel sebab. Variabel bebas (X) pada penelitian ini yaitu: (a) pendekatan Pembelajaran Matematika Realistik bernuansa Etnomatematik (PMRE) yang diberikan pada kelas eksperimen, (b) pembelajaran kovensional yang diberikan kepada kelas kontrol. Variabel terikat yaitu variabel yang dipengaruhi atau yang menjadi akibat karena adanya variabel bebas (Sugiyono, 2013). Variabel terikat (Y) pada penelitian ini adalah kemampuan komunikasi matematis. Variabel kontrol adalah variabel yang dikendalikan atau dibuat konstan sehingga hubungan variabel bebas terhadap variabel terikat tidak dipengaruhi oleh faktor luar yang tidak diteliti. Variabel kontrol sering digunakan peneliti, bila akan melakukan penelitian yang bersifat membandingkan (Sugiyono, 2013). Variabel kontrol (Z) pada penelitian ini adalah kemampuan awal matematika siswa (tinggi, sedang, rendah). Adapun hubungan keterkaitan antar variabel dapat ditunjukkan dalam tabel 1 berikut

\section{Tabel 1. Keterkaitan antara Kemampuan yang Diukur, Pembelajaran, dan Kemampuan Awal Matematis Siswa}

\begin{tabular}{cccc}
\hline & & \multicolumn{2}{c}{ Komunikasi Matematis (KM) } \\
\cline { 3 - 4 } & & PMRE & PK \\
\hline Kemampuan Awal Matematis & Tinggi (T) & KMT-PMRE & KMT-PK \\
(KAM) & Sedang (S) & KMS-PMRE & KMS-PK \\
& Rendah (R) & KMR-PMRE & KMR-PK \\
\hline
\end{tabular}

Keterangan: PMRE (Pembelajaran Matematika Realistik bernuansa Etnomatematik), PK (Pembelajaran Konvensional) 
Contoh:

KMT-PMRE :Kemampuan komunikasi matematis (KM) siswa dengan KAM tinggi (T) dan mendapat pembelajaran matematika realistiketnomatematik (PMRE).

Pengelompokkan siswa berdasarkan KAM dilakukan bertujuan untuk mengetahui pengetahuan siswa sebelum pembelajaran dan digunakan sebagai dasar pengelompokkan siswa berdasarkan kemampuan awal matematisnya. Kemampuan awal matematis siswa diukur melalui hasil ulangan harian, ujian tengah semester dan ujian semester. Kategori pengelompokan siswa berdasarkan KAM dari rataan dan standar deviasi (Arikunto, 2013). Hasil pengelompokan dapat dilihat pada tabel 2 sebagai berikut.

\section{Tabel 2. Hasil Pengelompokan Siswa Berdasarkan Kategori KAM}

\begin{tabular}{cc}
\hline Kategori & Jumlah Siswa \\
\hline Tinggi & 9 \\
\hline Sedang & 45 \\
\hline Rendah & 10 \\
\hline
\end{tabular}

Teknik pengumpulan data dalam penelitian ini menggunakan instrumen tes dan non tes. Instrumen tes berupa soal kemampuan komunikasi matematis dan instrumen non tes berupa lembar observasi. Adapun untuk soal kemampuan komunikasi matematis terdiri atas 4 soal uraian yang digunakan untuk pretes dan postes. Indikator kemampuan komunikasi matematis yang akan digunakan dalam perancangan soal test yaitu: 1) Menggunakan simbol/notasi, operasi matematika secara tepat guna. 2) Mengekspresikan, mendemonstrasikan dan melukiskan ide-ide matematika ke dalam bentuk gambar, tabel, grafik atau model matematika lain. 3) Menyatakan suatu situasi, gambar, diagram, atau benda nyata ke dalam bahasa, simbol, idea, atau model matematika. 4) Menganalisis, mengevaluasi dan mengajukan pertanyaan terhadap suatu informasi yang diberikan.

Soal pretes dan postes sebelumnya di validasi secara teoritis yaitu validasi dan konstruk yang melibatkan dosen dan guru matematika sebagai validator. Setelah melalui revisi akhirnya soal diujikan secara empiris, hasil uji validitas dan reliabilitas soal tes kemampuan komunikasi matematis menunjukkan hasil yang valid dan reliabel. Untuk melihat validitas butir soal tes digunakan Model Rasch. Uji validitas ini dilakukan dengan bantuan software Winstep 3.73. Hal yang dilihat adalah berdasarkan nilai Outfit Mean 
Square (MNSQ), Outfit Z-Standard (ZSTD), dan Point Measure Correlation (Pt Mean Corr). Dengan kriteria menurut (Sumintono \& Widhiarso, 2014). Hasil yang diperoleh dari uji validitas tes komunikasi matematis adalah sebagai berikut:

Tabel 3. Hasil Uji Validitas Tes Kemampuan Komunikasi Matematis

\begin{tabular}{cccccc}
\hline No Soal & Outfit MNSQ & Outfit ZSTD & Pt Mean Corr & Kesimpulan & Keterangan \\
\hline 1 & 1,25 & 1,0 & 0,68 & Diterima & Digunakan \\
2 & 0,79 & $-0,9$ & 0,58 & Diterima & Digunakan \\
3 & 0,68 & $-1,5$ & 0,81 & Diterima & Digunakan \\
4 & 1,23 & 1,0 & 0,85 & Diterima & Digunakan \\
\hline
\end{tabular}

Bila butir tes kemampuan komunikasi matematis memenuhi setidaknya dua kriteria di atas, maka butir soal atau pernyataan tersebut dapat digunakan, dengan kata lain butir tesebut valid. Berdasarkan tabel 3 untuk setiap butir soal kemampuan komunikasi matematis dapat diterima dan dapat digunakan dengan kata lain valid. Selanjutnya hasil perhitungan reliabilitas dari soal tes kemampuan komunikasi matematis yang telah di uji cobakan dapat dilihat pada tabel berikut:

Tabel 4. Reliabilitas Tes Kemampuan Komunikasi Matematis

\begin{tabular}{ccc}
\hline & Nilai Reliabilitas & Klasifikasi \\
\hline Reliabilitas Tes & 0,71 & Bagus \\
Reliabilitas Item & 0,82 & Bagus \\
\hline
\end{tabular}

Berdasarkan tabel 4 terlihat bahwa reliabilitas tes kemampuan komunikasi matematis berkategori "bagus" dengan $r_{11}=0,71$. Kemudian juga diperoleh nilai reliabilitas item yaitu 0,82 yang termasuk dalam kategori bagus. Dari kedua nilai tersebut dapat diartikan bahwa soal tes dan setiap butir soal tes kemampuan komunikasi matematis akan memberikan hasil yang hampir sama jika diujikan kembali kepada siswa.

\section{HASIL DAN PEMBAHASAN}

Hasil penelitian dan pembahasan dalam penelitian ini akan dipaparkan secara deskriptif dan menggunakan uji statistika inferensial. Hal ini untuk memperlihatkan hasil peningkatan kemampuan komunikasi matematis siswa pada materi persamaan dan 
pertidaksamaan linear satu variabel pada siswa yang mendapatkan PMRE dan pembelajaran konvensional baik ditinjau secara keseluruhan maupun berdasarkan KAM.

Berdasarkan hasil penelitian menunjukkan bahwa secara keseluruhan peningkatan kemampuan komunikasi matematis siswa yang memperoleh pendekatan pembelajaran matematika realistik bernuansa etnomatematik (PMRE) lebih baik daripada siswa yang memperoleh pembelajaran konvensional. Hal ini bisa dilihat pada nilai rerata postes pada kelas eksperimen sebesar 74,48 sementara pada kelas kontrol sebesar 60,21. Selain itu, rerata $n$-gain keseluruhan siswa yang mendapatkan PMRE 0,71 dengan kategori tinggi sedangkan n-gain mahasiswa yang mendapatkan pembelajaran konvensional sebesar 0,56. Adapun dapat dilihat pada tabel 5 berikut.

Tabel 5. Statisik Deskriptif Kemampuan Komunikasi MatematisBerdasarkan Kelas dan kategori KAM

\begin{tabular}{cccccccccc}
\hline \multirow{2}{*}{ KAM } & Stat. & \multicolumn{3}{c}{ Kontrol (Konvensional) } & \multicolumn{5}{c}{ Eksperimen (PMRE) } \\
& & Pretes & Postes & Gain & N & Pretes & Postes & Gain & N \\
\hline \multirow{2}{*}{ Tinggi } & $\bar{x}$ & 15 & 63,33 & 0,57 & & 10 & 66,67 & 0,64 & \\
& $\mathrm{~S}$ & 4,30 & 16,55 & 0,21 & & 10,54 & 18,10 & 0,17 & 5 \\
\multirow{2}{*}{ Sedang } & $\bar{x}$ & 9,99 & 62,27 & 0,58 & & 12,60 & 78,26 & 0,74 & \\
& $\mathrm{~S}$ & 4,93 & 15,37 & 0,16 & & 8,34 & 12,01 & 0,13 & \\
\multirow{2}{*}{ Rendah } & $\bar{x}$ & 8,89 & 50,56 & 0,46 & & 8,33 & 62,5 & 0,56 & \\
& $\mathrm{~S}$ & 3,44 & 7,12 & 0,07 & & 5,77 & 28,85 & 0,30 & \\
\multirow{2}{*}{ Keseluruhan } & $\bar{x}$ & 10,42 & 60,21 & 0,56 & & 11,67 & 74,48 & 0,71 & \\
& $\mathrm{~S}$ & 4,85 & 14,74 & 0,16 & & 8,34 & 12,26 & 0,17 & 32 \\
\hline
\end{tabular}

Selanjutnya untuk mengetahui apakah peningkatan kemampuan komunikasi matematis siswa yang memperoleh pendekatan Pembelajaran Matematika Realistik bernuansa Etnomatematik (PMRE) lebih baik daripada siswa yang memperoleh pembelajaran konvensional maka diajukan hipotesis sebagai berikut: Hipotesis 1, peningkatan kemampuan komunikasi matematis siswa yang memperoleh pendekatan Pembelajaran Matematika Realistik bernuansa Etnomatematik (PMRE) lebih baik daripada siswa yang memperoleh pembelajaran konvensional ditinjau secara keseluruhan. Hipotesis 2, Peningkatan kemampuan komunikasi matematis siswa kelompok KAM tinggi yang memperoleh pendekatan Pembelajaran Matematika Realistik bernuansa 
Etnomatematik (PMRE) lebih baik daripada siswa yang memperoleh pembelajaran konvensional. Hipotesis 3, Peningkatan kemampuan komunikasi matematis siswa kelompok KAM sedang yang memperoleh pendekatan Pembelajaran Matematika Realistik bernuansa Etnomatematik (PMRE) lebih baik daripada siswa yang memperoleh pembelajaran konvensional. Hipotesis 4, Peningkatan kemampuan komunikasi matematis siswa kelompok KAM rendah yang memperoleh pendekatan Pembelajaran Matematika Realistik bernuansa Etnomatematik (PMRE) lebih baik daripada siswa yang memperoleh pembelajaran konvensional

Keempat hipotesis tersebut akan dilakukan uji perbedaan rataan kemampuan komunikasi matematis namun sebelumnya dilakukan analisis uji prasyarat terlebih dahulu yaitu uji normalitas dan uji homogenitas varians. Uji normalitas data pada kelas yang diterapkan PMRE maupun PK baik ditinjau secara keseluruhan maupun berdasarkan KAM siswa semuanya berdistribusi normal. Selanjutnya dilakukan uji homogenitas data dan didapat hasil bahwa ditinjau secara keseluruhan data homogen namun berdasarkan KAM hanya KAM tinggi dan sedang yang menunjukkan varians antar data homogen sementara pada kelompok KAM rendah data tidak homogen. Hal ini berarti pada data keseluruhan, KAM tinggi dan sedang dilakukan uji perbedaan rataan menggunakan menggunakan uji Independent Sample t-test dengan taraf signifikansi 0,05 dan hasilnya nanti akan dilihat pada nilai signifikansi pada baris Equal Variances Assumed. Namun untuk kelompok KAM rendah yang diketahui datanya berdistribusi normal namun tidak homogen, akan tetap menggunakan uji Independent Sample t-test dengan taraf signifikansi 0,05 namun hasilnya nanti akan dilihat pada nilai signifikansi pada baris Equal Variances not Assumed. Adapun hasilnya ditunjukkan pada tabel 6 berikut

Tabel 6. Uji Perbedaan Rataan Kemampuan Komunikasi Matematis ditinjau Secara Keseluruhan dan Berdasarkan KAM

\begin{tabular}{cccc}
\hline Hipotesis & Uji Statistik & Sig. & Keputusan \\
\hline $\begin{array}{c}\text { Hipotesis 1 } \\
\text { Peningkatan (N-Gain) Keseluruhan }\end{array}$ & Uji Independent Sampel t-test & 0,000 & $\mathrm{H}_{0}$ ditolak \\
Hipotesis 2 & & & \\
KAM Tinggi & Uji Independent Sampel t-test & 0,279 & $\mathrm{H}_{0}$ diterima \\
$\begin{array}{c}\text { Hipotesis 3 } \\
\text { KAM Sedang } \\
\text { Hipotesis 4 }\end{array}$ & Uji Independent Sampel t-test & 0,0005 & $\mathrm{H}_{0}$ ditolak \\
KAM Rendah & Uji Independent Sampel t-test & 0,2185 & $\mathrm{H}_{0}$ diterima \\
\hline
\end{tabular}


Pada tabel 6 didapat hasil untuk uji perbedaan rataan KKM siswa yang mendapatkan PMRE dan siswa yang mendapatkan $\mathrm{PK}, \mathrm{H}_{0}$ ditolak untuk hipotesis 1 dan 3 yaitu pada peningkatan KKM ditinjau secara keseluruhan dan juga pada KAM sedang. Sedangkan untuk hipotesis 2 dan $4 \mathrm{H}_{0}$ diterima. Berikut ini deskripsi pengambilan keputusan berdasarkan hipotesis masing-masing: 1) Peningkatan kemampuan komunikasi matematis siswa yang memperoleh pendekatan Pembelajaran Matematika Realistik bernuansa Etnomatematik (PMRE) lebih baik daripada siswa yang memperoleh pembelajaran konvensional ditinjau secara keseluruhan. 2) Peningkatan kemampuan komunikasi matematis siswa kelompok KAM tinggi yang memperoleh pendekatan Pembelajaran Matematika Realistik bernuansa Etnomatematik (PMRE) tidak lebih baik daripada siswa yang memperoleh pembelajaran konvensional. 3) Peningkatan kemampuan komunikasi matematis siswa kelompok KAM sedang yang memperoleh pendekatan Pembelajaran Matematika Realistik bernuansa Etnomatematik (PMRE) lebih baik daripada siswa yang memperoleh pembelajaran konvensional. 4) Peningkatan kemampuan komunikasi matematis siswa kelompok KAM rendah yang memperoleh pendekatan Pembelajaran Matematika Realistik bernuansa Etnomatematik (PMRE) tidak lebih baik daripada siswa yang memperoleh pembelajaran konvensional

Berdasarkan pemaparan di atas, peningkatan KKM siswa secara keseluruhan untuk kelas eksperimen yang mendapat PMRE lebih baik daripada kelas kontrol yang mendapatkan PK. Hal yang sama juga untuk KAM sedang KKM siswa yang mendapatkan PMRE lebih baik daripada siswa yang mendapatkan PK dengan kategori tinggi. Hal ini berarti PMRE memberikan pengaruh signifikan lebih baik terhadap kemampuan komunikasi matematis siswa. Sementara itu, berbeda untuk KAM tinggi dan sedang, hasilnya didapatkan bahwa siswa yang mendapatkan PMRE tidak lebih baik dibandingkan siswa yang mendapatkan PK. Hal ini juga terjadi pada penelitian Bunga, Isrok'atun dan Julia (2016) yang menghasilkan bahwa berdasarkan uji beda rata-rata terhadap nilai N-gain kemampuan komunikasi matematis, dapat dikatakan bahwa pembelajaran matematika dengan menggunakan pendekatan RME tidak lebih baik daripada pembelajaran matematika konvensional dalam meningkatkan kemampuan komunikasi matematis siswa.

Pada pembahasan di atas, telah terjadi temuan bahwa terdapat penerimaan hipotesis statistik (yang diharapkan ditolak) pada hipotesis 2 dan 4 yaitu pada KAM tinggi dan rendah. Hipotesis yang didapat adalah kelas eksperimen tidak lebih baik dibandingkan 
kelas kontrol. Hal ini terjadi dikarenakan beberapa faktor, seperti ketika pengelompokan KAM belum menggambarkan sebenarnya kemampuan siswa dan penyebab lain ketika pembelajaran seperti siswa kurang serius dalam menerima pembelajaran, mengantuk, malas dan lain sebagainya.

Selanjutnya peneliti juga menganalisis kemampuan komunikasi matematis siswa berdasarkan indikator yang dipakai. Bila dilihat berdasarkan indikator kemampuan komunikasi matematis yang digunakan dalam penelitian ini, yaitu: (1) Menggunakan simbol/notasi, operasi matematika secara tepat guna; (2) Mengekspresikan, mendemonstrasikan dan melukiskan ide-ide matematika ke dalam bentuk gambar, tabel, grafik atau model matematika lain; (3) Menyatakan suatu situasi, gambar, diagram, atau benda nyata ke dalam bahasa, simbol, idea, atau model matematika; (4) Menganalisis, mengevaluasi dan mengajukan pertanyaan terhadap suatu informasi yang diberikan, maka persentase pencapaian kemampuan komunikasi matematis siswa di kelas eksperimen pada setiap indikator lebih tinggi daripada kelas kontrol. Hal ini dapat dilihat pada tabel berikut:

\section{Tabel 7. Pencapaian Kemampuan Komunikasi Matematis Berdasarkan Indikator}

\begin{tabular}{|c|c|c|c|c|c|c|}
\hline \multirow{3}{*}{ Pembelajaran } & \multirow{2}{*}{ STAT. } & \multicolumn{4}{|c|}{ INDIKATOR } & \multirow{2}{*}{ TOTAL } \\
\hline & & 1 & 2 & 3 & 4 & \\
\hline & Skor Total & 6 & 7 & 8 & 9 & 30 \\
\hline \multirow{2}{*}{ PMRE } & $\overline{\boldsymbol{x}}$ & 1,84 & 2,56 & 2,62 & 2,14 & 22,34 \\
\hline & $\%$ & 92,18 & 73,21 & 65,65 & 71,52 & 74,47 \\
\hline \multirow{2}{*}{ PK } & $\overline{\boldsymbol{x}}$ & 1,92 & 2,40 & 1,93 & 1,19 & 18,06 \\
\hline & $\%$ & 96,35 & 68,75 & 48,43 & 26,62 & 60,20 \\
\hline
\end{tabular}

Berdasarkan tabel $7 \mathrm{di}$ atas, terlihat bahwa pada keempat indikator kemampuan komunikasi matematis yang digunakan pada penelitian ini, persentase pencapaian kemampuan komunikasi matematis siswa yang belajar dengan pembelajaran PMRE lebih tinggi daripada siswa yang belajar dengan pembelajaran konvensional. Bila dilihat dari pencapaian kemampuan komunikasi matematis siswa dibandingkan dengan skor maksimum ideal, memperlihatkan bahwa pencapaian kelas eksperimen adalah $74,47 \%$ 
sedangkan kelas kontrol 60,20\%. Pencapaian kelas eksperimen lebih tinggi dibandingkan kelas kontrol. Hal dapat divisualisasikan pada gambar di bawah ini:

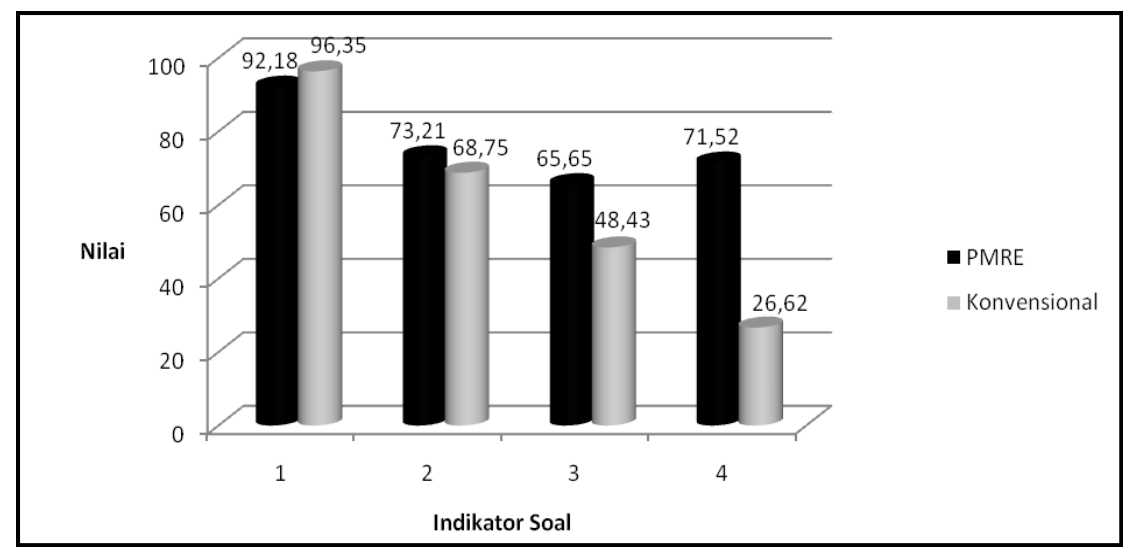

\section{Gambar 1. Persentase Pencapaian Kemampuan Komunikasi Matematis Siswa Berdasarkan Indikator}

Pada indikator 1 yaitu menggunakan simbol/notasi, operasi matematika secara tepat gunadengan soal: Nyatakan setiap pernyataan berikut dengan menuliskannya dalam bentuk matematika yang tepat. a. Tiga kali banyak uang ayah sama dengan banyak uang ayah ditambah Rp100.000,00, b. Banyaknya pensil Ida menjadi 50 buah setelah dibelikan ayahnya sebanyak 23 buah., c. Dua kali suatu bilangan jika ditambah dengan lima hasilnya sama dengan 27. Salah satu contoh jawaban siswa dapat dilihat pada gambar 2

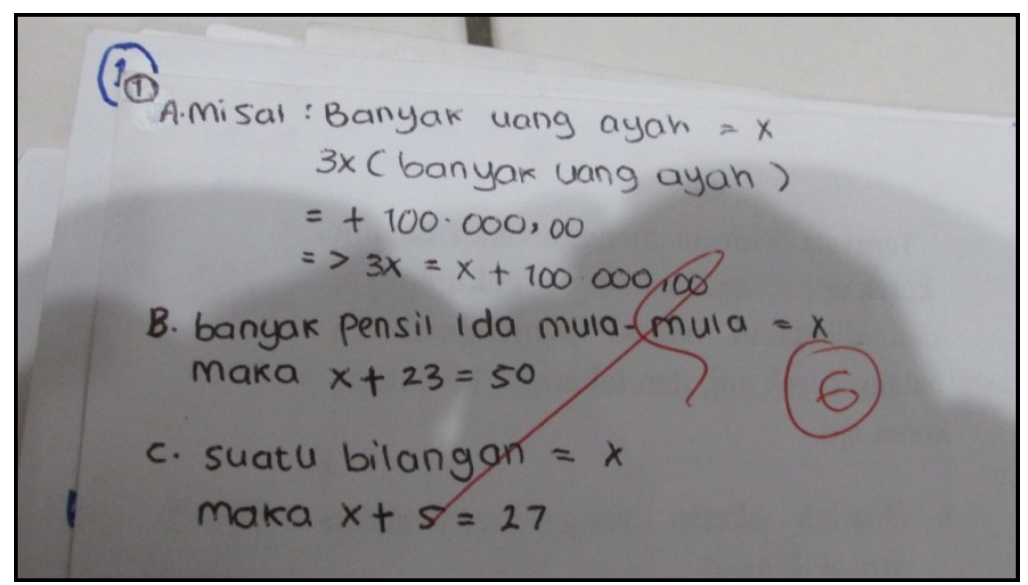

Gambar 2. Jawaban Salah Satu Siswa Kelas Eksperimen untuk Indikator 1 
Pada gambar 2 terlihat bahwa siswa dapat menggunakan symbol atau/notasi yang diberikan secara tepat guna. Siswa juga memperlihatkan kemampuannya dalam mengubah bentuk soal cerita menjadi kalimat matematika yang benar. Sebagian besar siswa $(92,18 \%)$ pada kelas eksperimen menjawab dengan benar untuk soal no 1. Begitupun untuk siswa kelas kontrol sebagian besar siswa $(96,35 \%)$ juga menjawab dengan benar.

Untuk melihat bagaimana siswa mengekspresikan, mendemonstrasikan dan melukiskan ide-ide matematika ke dalam bentuk gambar, tabel, grafik atau model matematika lain (indikator 2) maka diberikan persoalan berikut; Telah diketahui jembatan gantung terpanjang di dunia adalah Akashi Kaikyo (Jepang) yang memiliki panjang 1.991 meter. Jepang juga memiliki jembatan Shimotsui Straight. Jembatan Akashi Kaikyo memiliki panjang 111 meter lebih panjang dari dua kali panjang jembatan Shimotsui Straight. a. Nyatakanlah situasi di atas dalam bentuk gambar yang mudah dipahami, $b$. Berapakah panjang jembatan Shimotsui Straight?

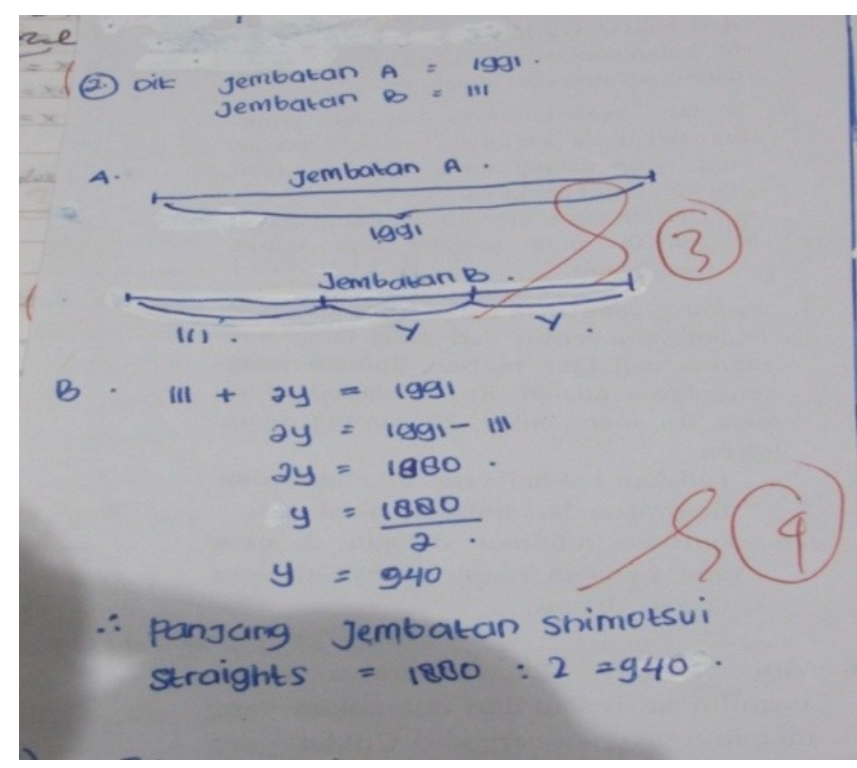

\section{Gambar 3. Jawaban Salah Satu Siswa Kelas Eksperimen untuk Indikator 2}

Pada gambar 3 terlihat siswa pada kelas eksperimen $(73,1 \%)$ telah mampu mengekspresikan persoalan kehidupan sehari dalam bentuk gambar dan menyelesaikannya ke dalam model matematika. Untuk kelas kontrol hanya 68,75\% siswa mampu untuk menggambarkan dan menyelesaikan persoalan ke dalam bentuk model matematika. Selanjutnya didapatkan temuan untuk indikator ke tiga dan ke empat yaitu; 
(3) menerapkan berbagai strategi yang tersusun dan memberikan alasan untuk menentukan serta menerapkan standar tersebut; (4) menemukan dan mendeteksi hal-hal penting dalam soal serta menarik kesimpulan dengan tepat, persentase kemampuan komunikasi matematis siswa kelas eksperimen $(65,65 \%$ dan $71,52 \%)$ dan kelas kontrol $(48,43 \%$ dan $26,62 \%)$ lebih rendah dibandingkan dua indikator sebelumnya namun secara keseluruhan kelas eksperimen lebih baik dibandingkan kelas kontrol. Namun untuk kedua indikator terlihat bahwa siswa mengalami kesulitan dalam penyelesaian soal baik di kelas eksperimen maupun di kelas kontrol. Untuk itu masih perlu pengembangan pembelajaran PMRE agar didapat hasil yang optimal dalam meningkatkan kemampuan komunikasi matematis siswa.

Pada penelitian ini didukung pula dengan hasil lembar observasi aktifitas siswa. Secara keseluruhan terlihat bahwa siswa aktif dalam pembelajaran PMRE dikarenakan menggunakan alat peraga inovatif dan juga membuat siswa bekerjasama dalam kelompoknya. Berikut disajikan hasil lembar observasi aktifitas siswa.

Tabel 8. Tabel Lembar Observasi Aktivitas Siswa

\begin{tabular}{|c|c|c|c|c|c|}
\hline \multirow[b]{2}{*}{ No } & \multirow[b]{2}{*}{ Aspek yang diamati } & \multicolumn{4}{|c|}{ Hasil Pengamatan } \\
\hline & & $\begin{array}{l}\text { Sangat } \\
\text { Aktif }\end{array}$ & Aktif & $\begin{array}{l}\text { Cukup } \\
\text { Aktif }\end{array}$ & $\begin{array}{l}\text { Tidak } \\
\text { Aktif }\end{array}$ \\
\hline 1 & $\begin{array}{l}\text { Berbagi ide dengan temannya pada saat diskusi dalam } \\
\text { kelompok masing-masing }\end{array}$ & & $\sqrt{ }$ & & \\
\hline 2 & Berbagi ide dengan temannya pada saat diskusi kelas & & & $\sqrt{ }$ & \\
\hline 3 & $\begin{array}{l}\text { Berusaha mencari buku sumber jika mengalami kesulitan } \\
\text { dalam menyelesaikan tugas }\end{array}$ & & $\sqrt{ }$ & & \\
\hline 4 & $\begin{array}{l}\text { Menjawab pertanyaan dari guru atau dari temannya ketika } \\
\text { diskusi }\end{array}$ & & $\sqrt{ }$ & & \\
\hline 5 & $\begin{array}{l}\text { Bertanya kepada guru ketika kelompoknya mengalami } \\
\text { kesulitan dan gagal mencari solusinya }\end{array}$ & & $\sqrt{ }$ & & \\
\hline \multirow[t]{2}{*}{6} & $\begin{array}{l}\text { Memeriksa pekerjaan kelompok lain yang disajikan di de- } \\
\text { pan }\end{array}$ & & & $\sqrt{ }$ & \\
\hline & & Ya & Cukup & Kurang & Tidak \\
\hline 7 & $\begin{array}{l}\text { Melaksanakan tugas yang diberikan, baik tugas kelompok } \\
\text { maupun tugas individu }\end{array}$ & $\sqrt{ }$ & & & \\
\hline 8 & Menggunakan jawaban sendiri & & $\sqrt{ }$ & & \\
\hline 9 & Membuat rangkuman & $\sqrt{ }$ & & & \\
\hline
\end{tabular}


Hal yang menjadi unik dalam penelitian ini adalah penggunaan etnomatematika dalam pembelajarannya. Hal ini mungkin juga menjadi sebab siswa aktif dalam pembelajaran. Etnomatematika yang digunakan adalah konteks masyarakat Suku Anak Dalam (SAD) yang telah dibahas pada penelitian (Muslimahayati, 2015). Konteks dalam pendekatan PMRE ini diantaranya berupa budaya masyarakat SAD dan aktivitas mengukur dengan menggunakan sto, kilan dan depo. Sebagai contoh pada kalimat berikut: 1) Masyarakat Suku Anak Dalam (SAD) adalah masyarakat /suku khas dari provinsi Jambi, 2) Upacara Besale adalah upacara adat pernikahan dimasyarakat Suku Anak Dalam (SAD), 3) Ketek adalah perahu tradisional yang biasa digunakan masyarakat SAD untuk menyeberang atau untuk mencari ikan di sungai

Kalimat-kalimat di atas digunakan sebagai contoh pada materi persamaan dan pertidaksamaan linear satu variabel dimana para siswa terlebih dahulu dikenalkan dengan apa yang dimaksud dengan pernyataan, bukan pernyataan, kalimat tertutup dan kalimat terbuka. Kalimat-kalimat tersebut dimasukkan dengan tambahan kalimat yang lain kemudian para siswa diminta untuk mengelompokkan kalimat tersebut termasuk dalam pernyataan, bukan pernyataan, kalimat tertutup atau kalimat terbuka. Hal ini dimaksudkan agar siswa merasa lebih dekat dengan pembelajaran matematika dikarenakan masalah yang diberikan berkenaan dengan kehidupan sehari-hari. Terkait dengan kemampuan komunikasi matematis, permasalahan yang diberikan ini bersesuaian dengan indikator ketiga yaitu siswa mampu menyatakan suatu situasi, gambar, diagram, atau benda nyata ke dalam bahasa, simbol, idea, atau model matematika.

Pada kegiatan yang lain, siswa juga diberikan kesempatan untuk melakukan aktivitas mengukur dengan menggunakan teknik pengukuran masyarakat $\mathrm{SAD}$ yang dikenal dengan istilh kilan, sto dan depo seperti terlihat pada gambar di bawah ini. 


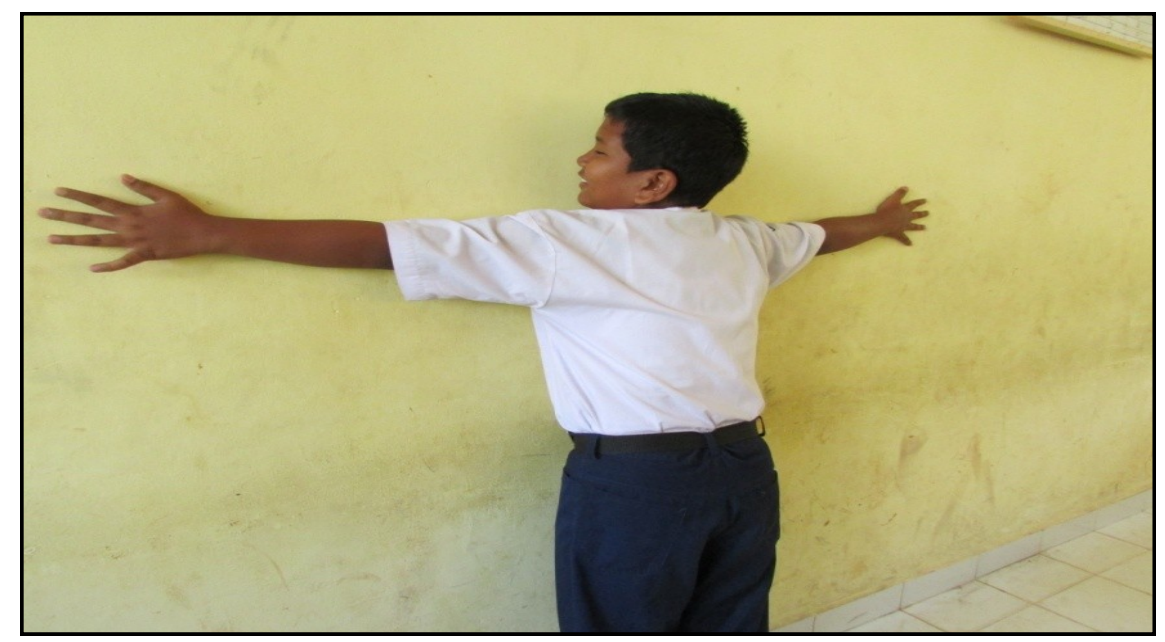

\section{Gambar 4. Siswa sedang Mengukur Panjang Dinding dengan Merentangkan Kedua Tangannya (depo)}

Hal ini juga memperlihatkan bahwa pendekatan etnomatematika juga bisa digunakan dalam pembelajaran. Interaksi dan aktivitas siswa dalam kegiatan ini membuat pembelajaran menjadi menyenangkan. Penelitian yang dilakukan oleh (S. Sirate, 2012) juga menunjukkan bahwa penerapan etnomatematika sebagai sarana untuk memotivasi, menstimulasi siswa,dapat mengatasi kejenuhan dan kesulitan dalam belajar matematika. Hal ini disebabkan etnomatematika merupakan bahagian dari keseharian siswa yang merupakan konsepsi awal yang telah dimiliki dari lingkungan sosial budaya setempat. Selain itu etnomatematika memberikan nuansa baru pada pembelajaran matematika. Penelitian (Fajriyah, 2018) juga menunjukkan bahwa etnomatematika menyediakan lingkungan pembelajaran yang menciptakan motivasi yang baik dan lebih menyenangkan sehingga siswa memiliki minat yang besar dalam mengikuti pembelajaran matematika yang diharapkan dapat mempengaruhi kemampuan matematika mereka.

Oleh karena itu, terlihat kelas yang diberikan pembelajaran matematika realistik bernuansa etnomatematika bekerja bagus dalam kelompok dan menuntut kerja yang lebih bermakna dan berbasis pada masalah. Dengan proses tersebut akan mengembangkan kecakapan berpikir siswa baik diajarkan oleh guru secara langsung atau memadukannya dalam materi pelajaran sehingga kemampuan komunikasi matematis siswa lebih meningkat. 


\section{SIMPULAN}

Berdasarkan hasil penelitian dan pembahasan yang telah dikemukakan, disimpulkan bahwa ditinjau secara keseluruhan peningkatan kemampuan komunikasi matematis siswa yang memperoleh pendekatan pembelajaran matematika realistik bernuansa etnomatematik (PMRE) lebih baik daripada siswa yang memperoleh pembelajaran konvensional dengan kategori tinggi. Jika ditinjau berdasarkan KAM siswa, peningkatan kemampuan komunikasi matematis siswa kelompok KAM sedang yang memperoleh pendekatan pembelajaran matematika realistik bernuansa etnomatematik (PMRE) lebih baik daripada siswa yang memperoleh pembelajaran konvensional, namun untuk KAM tinggi dan rendah diperoleh bahwa peningkatan kemampuan komunikasi matematis siswa yang memperoleh pendekatan pembelajaran matematika realistik bernuansa etnomatematik (PMRE) tidak lebih baik daripada siswa yang memperoleh pembelajaran konvensional. Oleh karena itu, peneliti menyarankan untuk melakukan tes terlebih dahulu untuk mengelompokkan siswa berdasarkan KAM tinggi, sedang dan rendah agar meminimalisir kesalahan dalam analisis. 


\section{DAFTAR PUSTAKA}

Arikunto, S. (2013). Prosedur Penelitian: Suatu Pendekatan Praktik (Edisi Revisi). In Jakarta: Rineka Cipta. https://doi.org/10.1017/CBO9781107415324.004

Asikin, M., \& Junaedi, I. (2013). Kemampuan Komunikasi Matematika Siswa SMP dalam Setting Pembelajaran RME (REalistic Mathematics Education). Unnes Journal of Mathematics Education Research , 2 (1), 203-213.

De'Ambrosio. (1999). Literacy, Matheracy, dan Thechnoracy: A Trivium for Today. Math Think Learn , 1 (2), 131-153.

Fajriyah, E. (2018). Peran Etnomatematika Terkait Konsep Matematika dalam Mendukung Literasi. Prisma, Seminar Nasional Matematika. 1, pp. 114-119. Semarang: Universitas Negeri Semarang.

Isrok'atun, I. (2009). Meningkatkan Komunikasi Matematik Siswa SMP Melalui Realistic Mathematics Education (RME) dalam Rangka Menuju Sekolah Bertaraf Internasional (SBI). Retrieved from http://file.upi.edu/Direktori/JURNAL/ P E N D I D I K A N_D A S A R/N o m o r_1 1 - A p r i 1_2009/ MENINGKATKAN_KOMUNIKASI_MATEMATIK_SISWA_SMP_MELALUI REALISTIC_M A T HEM A T I C S_EDUCA T I O $\overline{\mathrm{N}} \% \overline{2} 8 \mathrm{RME} \%$ 29_DALAM_RANGKA_MENUJU_SEKOLAH_BERTARAF_INTERNASIONA L_\%28SBI\%29.pdf

Izzati, N., \& Suryadi, D. (2010). Komunikasi matematik dan pendidikan matematika realistik. Prosiding Seminar Nasional Matematika Dan Pendidikan Matematika, 721-729.

Kaselin, Sukestiyarno, \& Waluya, B. (2012). Kemampuan Komunikasi Matematis pada Pembelajaran Matematika dengan Strategi REACT Berbasis Etnomatematika. Journal of Mathematics Educational Research , 2 (2), 121-127.

Marsigit, M., Conromukti, R., Setiana, D. S., \& Hardiarti, S. (2018). Pengembangan Pembelajaran Matematika Berbasis Etnomatematika. Seminar Nasional Pendidikan Matematika Etnomatnesia (pp. 20-38). Yogyakarta: Universitas Sarjanawiyata Tamansiswa.

Muslimahayati, M. (2015). Peningkatan Kemampuan Komunikasi Matematis dan Berpikir Kritis Siswa dengan Pendekatan Pembelajaran Matematika Realistik Bernuansa Etnomatematik (PMRE). In U. P. Indonesia, Thesis. Bandung: Universitas Pendidikan Indonesia.

Muslimahayati, M., \& Wardani, A. K. (2019). Implementasi Etnomatematika Masyarakat Suku Anak Dalam (SAD) Kabupaten Batanghari Provinsi Jambi pada Pembelajaran Matematika. Jurnal Elemen, 5(2), 108. https://doi.org/10.29408/ jel.v5i2.957

NCTM. (1989). Cirriculum and Evaluation Standars for School Mathematis. Reston VA: NCTM. 
Putri, A. D., Syutaridho, S., Paradesa, R., \& Afgani, M. W. (2019). Peningkatan Kemampuan Komunikasi Matematis Mahasiswa Melalui Inovasi Pembelajaran Berbasis Proyek. JNPM (Jurnal Nasional Pendidikan Matematika), 3(1), 135. https://doi.org/10.33603/jnpm.v3i1.1884

Qohar, A., \& Sumarmo, U. (2013). Improving mathematical communication ability and self regulation learning of yunior high students by using reciprocal teaching. Journal on Mathematics Education, 4(1), 59-74.

S. Sirate, F. (2012). IMPLEMENTASI ETNOMATEMATIKA DALAM PEMBELAJARAN MATEMATIKA PADA JENJANG PENDIDIKAN SEKOLAH DASAR. Lentera Pendidikan : Jurnal Ilmu Tarbiyah Dan Keguruan, 15(1), 41-54. https://doi.org/10.24252/lp.2012v15n1a4

Sugiyono. (2013). Metode Penelitian Pendidikan Pendekatan Kuantitaif, Kualitatif, dan R\&D. Metode Penelitian Pendidikan Pendekatan Kuantitaif, Kualitatif, Dan R\&D, pp. 283-393. https://doi.org/10.1007/s13398-014-0173-7.2

Sumintono, B., \& Widhiarso, W. (2014). Aplikasi Model Rasch untuk Penelitian IlmuIlmu Sosial (Edisi Revisi). Bandung: Tim Komunikata Publishing House.

Turmidi, T. (2018). Kajian Etnomatematika: Belajar Matematika dengan Melibatkan Unsur Budaya. Seminar Nasional Etnomatnesia (pp. 38-53). Yogyakarta: Universitas Sanjanawiyata Tamansiswa.

Wijaya, A. (2012). Pendidikan Matematika Realistik, Suatu Alternatif Pendekatan Pembelajaran Matematika. Yogyakarta: Graha Ilmu. https://doi.org/10.21009/ jpd.061.11 